Laporan Kasus

\title{
Diagnosis dan Penatalaksanaan Hipofungsi Vestibular Perifer Bilateral
}

\author{
Ferdy Azman ${ }^{1}$, Yan Edward², Rossy Rosalinda ${ }^{2}$
}

\begin{abstract}
Abstrak
Pendahuluan: Hipofungsi vestibuler perifer bilateral merupakan kasus yang jarang ditemui dan memiliki gejala gangguan keseimbangan yang menyebabkan gangguan penglihatan dan stabilitas postural. Etiologi penyakit ini sebagian besar idiopatik, selain itu disebabkan oleh zat ototoksik, penyakit autoimun, infeksi dan neoplasma yang melibatkan telinga dalam. Diagnosa ditegakkan berdasarkan gejala klinis, pemeriksaan keseimbangan sederhana dan tes khusus seperti dynamic visual acuity test (DVA), Rotatory Chair dan elektronistagmografi (ENG) pada tes kalori sebagai standar baku. Tatalaksana hipofungsi vestibuler perifer bilateral terutama berupa terapi rehabilitasi vestibuler berupa terapi adaptasi, subtitusi dan kompensasi/ habituasi lebih dipilih jika dibandingkan dengan terapi farmakologis atau terapi bedah. Laporan Kasus: Seorang pasien usia 65 tahun datang dengan keluhan pusing berputar dan berkurangnya pendengaran. Pemeriksaan pendengaran menunjukkan hasil tuli sensorineural dan tes DVA menunjukkan adanya penurunan tiga baris huruf pada Snellen chart dan elektronistagmografi menunjukkan paresis kanal bilateral. Pasien didiagnosis dengan hipofungsi vestibuler perifer bilateral ec. suspek prebiastasis. Tatalaksana adalah dengan terapi rehabilitasi vestibuler dengan metode adaptasi. Simpulan: Hipofungsi vestibuler perifer bilateral merupakan kasus yang jarang ditemui, dapat dibedakan dengan pemeriksaan objektif spesifik yaitu elektronistagmografi. Terapi pilihan utama untuk penyakit ini adalah berupa terapi rehabilitasi vestibuler metode adaptasi, subtitusi dan habituasi
\end{abstract}

Kata kunci: Hipofungsi, vestibuler, bilateral, tes kalori, tes DVA, terapi rehabilitasi vestibuler

\begin{abstract}
Introduction: Billateral Vestibular hypofunction is a rare case which further caused gaze instability and postural instability. Most of this disorder are categorized as idiophatic, however other common etiologies included ototoxicity, autoimmune disease, infection and neoplasm of inner ear. Diagnosis are determined based on clinical manifestation, balance examination and specific test such as dynamic visual acuity testing, rotatory chair test, electronystagmography on a caloric test as gold standard. Treatment of choice is vestibular rehabilitation in the form of adaptation therapy, substitution and compensation/habituation, which considered better compare to medication and surgical treatment. Case report: patient 65 years old was admitted with main complaint of vertigo affected by position and body motion. $\mathrm{He}$ also complained for loss of hearing. Hearing examination showed sensorineural deafness and DVA test showed a decrease of three lines of letters on the Snellen chart and electronistagmography showed bilateral canal paresis. Patient was diagnosed with bilateral vestibular hypofunction and presbyastasis. Treatment of choice for this patient was vestibuler rehabilitation, specifically adaptation exercise. Conclusion: Bilateral vestibular periphere hypofunction is a rare case, can be distinguished from specific objective examination such as Elektronystagmography. As soon as diagnosis were made, first option for treatment is vestibular rehabilitation, divided as three methods: adaptation, substitution and habituation.
\end{abstract}

Keywords: Hypofunction, vestibular, bilateral, caloric test, DVA test, vestibular rehabilitation [Keywords]

Affiliasi penulis :1.PPDS THT-KL Fakultas Kedokteran Universitas Andalas. 2. Staf Bagian THT-KL Fakultas Kedokteran Universitas Andalas.

Korespondensi : ferdyazman@gmail.com Telp: 085356152156

\section{PENDAHULUAN}

Hipofungsi vestibular perifer secara umum ditandai oleh adanya vertigo, dizziness dan ketidakseimbangan yang menyebabkan gangguan penglihatan dan stabilitias postural. Hal ini dapat menimbulkan resiko jatuh terutama pada daerah yang gelap karena kemampuan visual tidak ada saat mengkompensasi suatu kelainan. ${ }^{1}$ Hipofungsi vestibular bilateral sendiri ditandai dengan adanya defek perifer dari labirin bilateral atau nervus kranial ke delapan, yang menyebabkan adanya gangguan pada refleks vestibulo-okuler, oscillopsia, disekuilibrum. ${ }^{1,2}$

Penyebab hipofungsi vestibular perifer bilateral sebagian besar idiopatik, selain itu disebabkan oleh penyakit autoimun, penyakit neoplasma atau kelainan pada telinga, serta ototoksik. Diagnosa hipofungsi vestibular bilateral ditegakkan berdasarkan gejala klinis, pemeriksaan keseimbangan sederhana dan pemeriksaan objektif yang dapat dilakukan adalah: dynamic visual acuity test (DVA), tes kalori, rotatory chair test, dan electronistagmografi. ${ }^{2,3}$

Tatalaksana hipofungsi vestibuler perifer bilateral berdasarkan pada prinsip fisiologis: adaptasi, subtitusi dan habituasi. Adaptasi vestibuler bertujuan untuk mengoptimalkan penggunaan informasi dari 
organ sensoris vestibuler. Rekalibrasi dari reflek vestibulookuler sebagai respon terhadap pembesaran atau pengecilan benda pada penggunaan kacamata yang merupakan salah satu bentuk terapi adaptasi. Sedangkan substitusi meliputi input sensoris dan atau respon selain dari yang berperan dalam kontrol vestibuler langsung. Sistem kompensasi/ habituasi seperti sistem somatosensoris, reflek servikookuler, dan juga sistem reflek halus dan sakkadis. ${ }^{4,5}$

\section{Anatomi}

Sistem vestibuler manusia berfungsi untuk memperkirakan posisi dan gerakan tubuh. Input gerakan tubuh pada sistem vestibuler meliputi sinyal dari telinga dalam (vestibuler) dan juga sensasi akan posisi (proprioseptif), sinyal visual, serta gerakan yang akan dilakukan (perintah motorik). ${ }^{5,6}$

Labirin tulang terdiri dari 3 kanalis semisirkularis (KSS), koklea, dan ruang antara keduanya yang disebut vestibula. Labirin tulang terisi oleh cairan perilimfe, yang secara kimiawi komposisinya mirip dengan cairan serebrospinal (rasio $\mathrm{Na}: \mathrm{K}$ yang tinggi). Cairan perilimfe berhubungan dengan cairan serebrospinal melalui akuaduktus koklea. Karena adanya pertemuan ini, penyakit yang mempengaruhi tekanan cairan spinal (seperti fungsi lumbal) juga dapat mempengaruhi fungsi telinga dalam. ${ }^{5-7}$

Arteri labirintin mensuplai aliran darah sistem vestibuler perifer. Arteri di labirin berasal dari beberapa sumber. Yang paling banyak dari cabang arteri serebelar inferior anterior (AICA). Labirin tidak memiliki anastomosis kolateral sehingga sangat rentan untuk terjadi iskemik. Terhambatnya aliran darah selama 15 detik, dapat mengganggu rangsangan nervus auditorius. 5,7

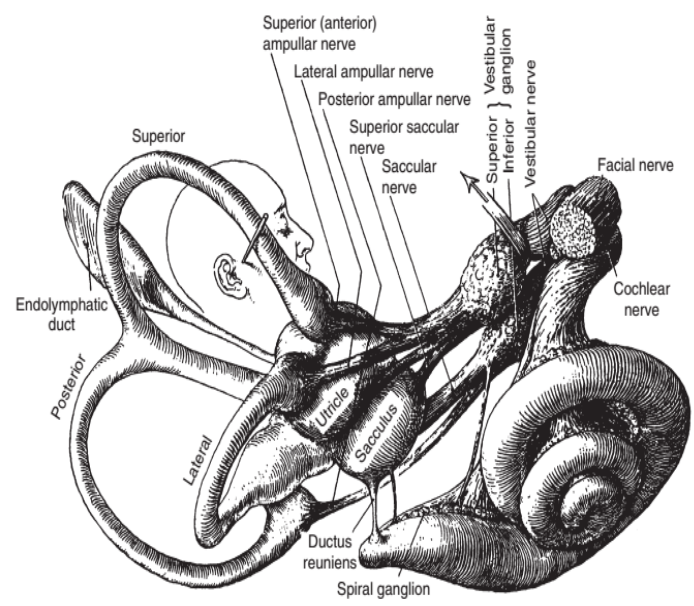

Gambar 1. Anatomi Kanalis Semisirkularis. ${ }^{6}$

\section{Reflek Vestibulo-Okuler}

Reflek Vestibulo-Okuler berfungsi dalam mempertahankan kestabilan suatu bayangan penglihatan selama pergerakan kepala secara rotasi, linier ataupun keduanya. Kepala yang digerakkan secara tiba-tiba maka secara reflek bola mata akan bergerak ke arah yang berlawanan dan bayangan obyeknya akan stabil di retina..$^{5,8}$

\section{Reflek Vestibulo-Spinal}

Reflek Vestibulo-Spinal bertujuan untuk menyeimbangkan tubuh. Refleks vestibulospinal pada dasarnya terdiri dari kumpulan beberapa refleks yang diberi nama sesuai dengan waktu terjadinya (dinamis vs statis atau tonik) dan input sensoris (kanal vs otolith). Contoh dari refleks vestibulospinal ini adalah urutan kejadian yang terlibat dalam menghasilkan refleks labirin. 5,7

\section{Epidemiologi}

Secara umum, keluhan utama pada pasien dengan gangguan vestibular adalah adanya ketidak seimbangan dan dizziness. Pada sebuah penelitian epidemiologis, dizziness dan vertigo memiliki prevalensi dengan rentang 5-10\%. ${ }^{9}$ Jika dikelompokkan lagi berdasarkan umur, keluhan ini umum ditemukan pada usia 40 tahun ke atas, dimana kedua keluhan ini merupakan keluhan utama pasien berusia 65 tahun ke atas untuk berobat ke dokter. Keluhan ini lebih banyak ditemukan pada wanita dibandingkan pria pada hampir seluruh kelompok umur, kecuali pada kelompok umur 70 tahun ke atas. 10

Prevalensinya bervariasi antara 28 hingga 81 per 100.000 orang, dan persentase hipofungsi vestibuler bilateral ditemukan pada pasien yang menjalani pemeriksaan ENG bervariasi antara 0.6 hingga $13.6 \% .{ }^{11,12}$

\section{Etiologi}

Hipofungsi vestibuler perifer bilateral sebagian besar dianggap idiopatik karena penyakit yang menyebabkannya tidak dapat diidentifikasi. Selain itu juga dapat terjadi sebagai akibat sekunder dari penyakit lain, seperti presbyastasis, ototoksik, meningitis, neuritis vestibuler sekuensial, penyakit autoimun, penyakit kongenital, dan neurofibromatosis. ${ }^{3,13}$

Penyebab ototoksitas yang paling sering adalah antibiotik golongan aminoglikosida dan agen kemoterapi. Antibiotik golongan aminoglikosida, gentamisin, mungkin merupakan penyebab tersering dari gangguan fungsi vestibuler bilateral berat. ${ }^{14,15}$

\section{Presbyastasis}

Salah satu penyebab hipofungsi vestibuler perifer yaitu penuaan pada sistem sensoris, sistem saraf pusat dan sistem motorik. Berikut ini yang menyebabkan terjadinya gangguan keseimbangan pada prebyastasis: Visual, proprioseptif, somatosensoris dan vestibular. ${ }^{16,17}$

Perubahan terkait usia dalam morfologi neuroepithelium vestibular yaitu kehilangan sel-sel rambut, serta pengurangan jumlah dari kinocilia dan stereosilia, terutama di bagian tengah atas daerah dari tiga ampula. Perubahan dalam metabolisme kalsium dari membran otolitik yang menua serta ischemia mikrovaskular juga memiliki pengaruh yang signifikan pada penurunan input vestibular pada populasi lanjut usia. 17,18 


\section{Diagnosis}

Gejala yang sering dirasakan pada hipofungsi vestibuler perifer bilateral meliputi ketidakseimbangan atau perasaan seperti akan jatuh dan biasanya ketidakseimbangan ini terutama dirasakan oleh pasien ketika berdiri atau berjalan dan mempengaruhi posisi postural pasien, ossilopsia yaitu kaburnya penglihatan di saat menggerakkan kepala, perasaan 'goyang', disekuilibrum, dan pusing (dizziness), kadang perasaan pusing dan tidak seimbang ini tidak mempengaruhi posisi postural pasien, serta perubahan aktivitas dan fisik yang biasanya terjadi karena ketidakseimbangan dan dizziness. ${ }^{2,3,13}$

Pemeriksaan neurotologi dan pemeriksaan vestibuler yang lengkap dan teliti diperlukan agar dapat ditemukannya tanda hipofungsi vestibuler perifer atau kelainan neurologis lainnya, terutama ataksia. Pada saat pemeriksaan neurotologi, pemeriksaan okulomotor hendaknya mendapat perhatian lebih, Karena ditemukannya kelainan okulomotor dapat berarti satu-satunya atau tanda pertama adanya kelainan vestibuler. ${ }^{2,19}$

Pemeriksaan vestibuler termasuk dix-Hallpike dan tes lateral roll, HIT, DVA, manuver valsava (menahan melawan glottis yang tertutup dan meniup dengan lubang hidung tertutup), tes head shake, tes vibrasi, tes hiperventilasi dan tes Romberg. Tes Romberg terutama digunakan untuk mendiagnosis ataksia dan tidak spesifik untuk gangguan fungsi vestibuler, Karena tes ini juga dapat mendeteksi gangguan serebelum dan propioseptif.9,12

Pemeriksaan bedside examination yang paling baik untuk gangguan vestibuler bilateral adalah tes dynamic visual acuity (DVA), yang disebut juga tes dynamic illegible. tes DVA dilakukan dengan membandingkan visus ketika kepala diam dengan ketika kepala diputar dari satu sisi ke sisi lain. Persyaratan tes ini bervariasi pada berbagai penelitian, tetapi secara umum, komponen osilasi dari tes ini meliputi rotasi sinusoidal pasif dari kepala pada plana horizontal dengan frekuensi 1 sampai $2 \mathrm{HZ}$, dengan pergeseran sebesar 15 hingga 30 derajat untuk masing-masing sisi. Visus pada masing-masing kondisi (pada saat kepala diam dan pada saat kepala bergerak), diukur dengan melihat garis terkecil pada Snellen eye chart yang bisa dibaca oleh pasien. , $12^{2}$

Nistagmus yang terjadi setelah menggerakkan kepala atau kurangnya VOR selama gerakan kepala cepat masing-masing merupakan indikasi gangguan perifer. Hilangnya kemampuan visual yang abnormal selama test dynamic visual acuity merupakan indikasi terganggunya fungsi VOR, tetapi tidak dapat digunakan untuk melokalisir letak lesi. ${ }^{13,20}$

Tes gaze yaitu dilakukan pemeriksaan fiksasi visual pada objek $30^{\circ}$ sisi kanan, kiri, atas dan bawah titik tengah dengan jarak $30 \mathrm{~cm}$. Nistagmus gazeevoked akan muncul saat dilakukan fiksasi visual yang merupakan tanda abnormalitas. Pada orang normal dapat muncul nistagmus gaze-evoked pada tempat gelap atau dengan mata tertutup. ${ }^{13,21}$

\begin{tabular}{|c|c|c|c|}
\hline \multirow{2}{*}{$\begin{array}{l}\text { Gans } \\
\text { Performance } \\
\text { pemeriksaan }\end{array}$} & \multicolumn{2}{|c|}{ Sensory } & Organization \\
\hline & $\begin{array}{l}\text { Test } \\
\text { untuk }\end{array}$ & $\begin{array}{l}\text { (SOP) } \\
\text { evaluasi }\end{array}$ & $\begin{array}{r}\text { merup } \\
\text { sta }\end{array}$ \\
\hline
\end{tabular}
sensoris yaitu visual, somatosensoris dan vestibular. Gangguan sistem sensoris individu atau gangguan respon adaptif dapat menyebabkan gangguan persepsi keseimbangan. ${ }^{22}$

Head impulse test (HIT). Teknik ini merupakan alternatif untuk mendeteksi gangguan vestibuler bilateral. Teknik ini mirip dengan DVA, tetapi bukannya mengukur visus, pemeriksa nanti akan menilai gerakan cepat mata (saccade) setelah perputaran kepala tiba-tiba. Karena hasil dari HIT tergantung kepada keahlian pemeriksa, dan hanya sedikit metode yang dapat mengkalibrasi kemampuan pemeriksa dengan pasien yang telah diketahui memiliki gangguan vestibuler bilateral, sensitifitas pemeriksaan ini dapat bervariasi. ${ }^{2,3}$

Pemeriksaan HIT juga membutuhkan kerja sama pasien, karena pasien harus dapat melakukan refiksasi gerakan mata volunter. Pergerakan kepala cepat bisa jadi sulit untuk ditoleransi pada pasien dengan nyeri leher atau kaku leher. Masalah lainnya adalah pasien dapat mengkompensasi teknik ini, dimana mereka perlahan akan belajar untuk menghasilkan sakadik antisipasi atau sakadik 'peralihan' selama pergerakan kepala cepat, sehingga mengeliminasi gerakan sakadik refiksasi yang semestinya. Menilik semua hal di atas, tes DVA lebih berguna dibandingkan dengan tes HIT untuk mendiagnosis gangguan vestibuler bilateral. 2,3,13

Selain bedside examination, terdapat beberapa pemeriksaan objektif untuk mendeteksi gangguan fungsi vestibuler yaitu elektronistagmografi (ENG). Sejarah awal digunakannya elektronistagmografi berawal dari tahun 1800an. Pada tahun 1800an, baru diketahui akan adanya arus listrik (voltage) dari mata dan berbeda-beda untuk setiap putaran mata. ${ }^{2,5}$

Potensi listrik korneo-retina (CRP) memiliki nilai dasar (pada saat mata diam dalam posisi netral), perbedaan potensi sebesar 1 millivolt dapat direkam dan teknik pertama yang dapat merekam gerakan mata disebut elektrooculopgraphy (EOG). Pada awal tahun 1900an, CRP telah menjadi metode standar untuk merekam gerakan mata. Dengan menggunakan elektroda yang diposisikan secara horizontal dan vertikal, CRP dapat dideteksi sebagai polaritas dari rotasi mata yang mendekati atau menjauhi elektroda. Karena rotasi mata torsional (putaran penuh searah jarum jam atau berlawanan jarum jam) tidak menyebabkan defleksi vertikal atau horizontal dari bola mata dalam orbit, elektroda tidak dapat mendeteksi perubahan relatif pada CRP. Sehingga, rotasi torsi pada mata tidak dapat dideteksi oleh EOG. Sebagai metode yang dikembangkan lebih lanjut untuk merekam rotasi mata, ENG juga dimaksudkan sebagai 
induk dari sederet pemeriksaan. Sehingga, pemeriksaan dengan ENG biasanya meliputi pengukuran fungsi oculomotor (termasuk stabilitas penglihatan, smooth pursuit, dan sakadik), test penempatan dan tes posisi, dan tes kalori), dengan adanya perkembangan dari perekaman pergerakan mata dengan video, sederetan tes ini (ENG) juga disebut sebagai VNG atau videonystagmography. ${ }^{5,11}$

Salah satu contoh pemeriksaan yang merupakan bagian dari ENG adalah rotatory chair test, dimana pemeriksaan ini merupakan salah satu pemeriksaan yang merupakan gold standard untuk diagnosis penurunan fungsi vestibuler bilateral. Rotatory chair test memungkinkan terjadinya stimulus fisiologis, yang disebabkan oleh gerakan memutar pasien akan menyebabkan aliran endolimfe (dengan eksitasi dan inhibisi relatif) dari kedua kanalis semisirkularis horizontal. ${ }^{5}$ Akan tetapi, rotatory chair test ini sangat mahal, sehingga hanya dapat dilakukan di pusat kesehatan besar. Meskipun varian rotatory chair test yang lebih murah, yaitu dengan menggunakan pergerakan kepala volunter atau otot pemeriksa, alat yang lebih murah tidak dapat mengevaluasi pada frekuensi rendah dan biasanya tidak lebih baik dibanding pemeriksaan lainnya. 3,8

\section{Tatalaksana}

Pada beberapa penelitian kasus hipofungsi vestibuler perifer yang kronis, tidak efektif diterapi farmakologis dan terapi bedah. Terapi farmakologis biasanya ditujukan untuk mensupresi vestibuler dan mengontrol gejala seperti mual atau untuk mengontrol penyebab penyakitnya misalnya infeksi. Terapi bedah memiliki manfaat yang terbatas dalam tatalaksana pasien dengan gangguan vestibuler. Terapi bedah dapat dilakukan sebagai 'usaha terakhir' pada pasien dengan gejala yang berkaitan dengan fluktuasi episodik pada fungsi perifer. Tindakan bedah dilakukan untuk menghilangkan fungsi dari struktur vestibuler (misalnya dengan cara labirintektomi) atau untuk menginterupsi input sentral dari sinyal vestibuler (dengan reseksi nervus vestibuler). Fungsi vestibuler yang berfluktuasi akan digantikan dengan defisit vestibuler menetap. ${ }^{13,23}$

Di sisi lain, tindakan bedah dapat membantu dalam kondisi tertentu seperti untuk mengatasi fistula perilimfatik atau mengangkat neuroma akustik. Terapi utama yang dipilih untuk tatalaksana gangguan vestibuler adalah rehabilitasi vestibuler, tatalaksana gangguan pendengaran dan tatalaksana faktor resiko. ${ }^{3,23}$

Kompensasi; reaksi kompensasi (untuk gejala posisional atau gejala yang dipicu gerakan), berdasarkan plastisitas inheren dari sistem saraf sentral dan menggunakan gerakan untuk menghabituasi atau mengurangi reaksi terhadap stimuli berulang dan untuk menyeimbangkan ulang atkivitas tonus di nuclei vestibuler. Meskipun proses ini sering dianggap sebagai proses 'pembiasaan', akan tetapi proses ini lebih sebagai proses kompensasi atau neuroplastik, bukannya respon pembiasaan sinaps fisiologis. . $^{93}$

Adaptasi untuk interaksi visual-vestibuler (stabilisasi pandangan) dan koordinasi tangan/mata, menggunakan gerakan repetitive dan provokatif kepala dan mata untuk mengurangi error dan mengembalikan reflek vestibulo-okuler (VOR). ${ }^{11,23}$

Substitusi yang dapat meningkatkan peran individu dari input sensoris (seperti visual atau somatosensoris) untuk membiaskan respon dari input vestibuler yang terganggu atau untuk membalikkan dengan memicu dan menguatkan reaksi kompensasi. ${ }^{5,23}$

Latihan kontrol postural, mencegah jatuh, latihan relaksasi, rekondisi aktivitas dan pelatihan fungsional/okupasional ulang, yang berdasarkan pada prinsip latihan motorik untuk mengubah kebiasaan dalam gerakan dan untuk meningkatkan efektifitas gerakan. Sebagai tambahan terdapat beberapa manuver reposisi spesifik yang dapat diintegrasikan ke dalam rehabilitasi vestibuler untuk kelompok pasien gangguan vestibuler tertentu (contohnya, maneuver pada BPPV). Manuver-manuver ini (reposisi canalith atau Epley's, Semont dan liberatory) dilakukan pada pasien dan berdasarkan kepada rasio mekanis untuk memposisikan debris vestibuler. ${ }^{22,23}$

\section{LAPORAN KASUS}

Seorang laki-laki usia 65 tahun datang ke Poliklinik RSUP Dr.M.Djamil Padang pada tanggal 17 Maret 2017 dengan keluhan utama pusing berputar sejak 1 minggu yang lalu. Pusing berputar pertama kali dirasakan pasien sewaktu baru bangun dari tidur sejak 2 bulan yang lalu, berlangsung sekitar 1 menit dan hilang timbul dengan frekuensi $2 x$ dalam sebulan. Saat pusing dirasakan seperti melihat benda-benda sekitar bergerak, disertai mual ada dan muntah tidak ada. Intensitas serangan makin lama makin berkurang. Penurunan pendengaran telinga kanan mendadak sejak 1 tahun yang lalu. Riwayat telinga berair tidak ada. Pasien mengkonsumsi kopi dan rokok sejak 40 tahun yang lalu. Riwayat terpapar bising yang lama tidak ada. Riwayat diabetes mellitus tidak ada. Riwayat mengkonsumsi obat-obatan tidak ada. Pasien tidak sensitif terhadap cahaya. Riwayat trauma kepala tidak ada, nyeri pada leher tidak ada.

Pemeriksaan status generalis didapatkan dalam batas normal. Pemeriksaan fisik pada kedua telinga didapatkan liang telinga lapang, membran timpani utuh reflek cahaya (+), sekret tidak ada. Pada pemeriksaan hidung dan tenggorok dalam batas normal. Tes penala semua frekuensi didapatkan kesan tuli sensorineural pada telinga kanan dan normal pada telinga kiri. Hasil audiogram telinga kanan didapatkan tuli sensorineural derajat sedang dengan ambang dengar 63,75 dB dan telinga kiri normal dengan ambang dengar 25 dB. Pada pemeriksaan keseimbangan sederhana didapatkan tes Romberg saat membuka dan menutup mata dapat dilakukan, Romberg dipertajam saat membuka dan menutup 
mata dapat dilakukan, Stepping test tidak terdapat deviasi. Tes koordinasi (Nose to finger test, Past Pointing test dan disdiadokinesis) dapat dilakukan. Pasien telah dilakukan rontgen servikal dengan kesan normal. Pada pemeriksaan gaze didapatkan hasil normal. Pada pemeriksaan head shaking dan head impulse test juga didapatkan hasil normal. Pemeriksaan dilanjutkan dengan melakukan manuver Dix-Hallpike kanan dan kiri, dengan hasil tidak ditemukan keluhan vertigo dan nistagmus. Selanjutnya pasien dilakukan tes dynamic visual aquity (DVA) dengan hasil terdapat penurunan tiga baris huruf pada baris huruf yang dapat dibaca pada snellen chart. Pada pemeriksaan schelong test didapatkan hasil yaitu tekanan darah saat berbaring $130 / 80 \mathrm{mmHg}$ dan berdiri 130/80 $\mathrm{mmHg}$. Pasien kemudian dilakukan tes elektronistagmografi dengan hasil yaitu paresis kanal bilateral dengan base line shift $0^{\circ}$.

Pada pemeriksaan laboratorium darah lengkap didapatkan kesan dislipidemia.

Pasien didiagnosis dengan hipofungsi vestibular perifer bilateral ec. Presbyastasis + Sudden deafness auris dekstra onset lama + dislipidemia. Pasien diterapi dengan terapi adaptasi dan anjuran penggunaan alat bantu dengar untuk telinga kanan serta dikonsulkan ke Penyakit Dalam untuk tatalaksana dislipidemia dan ke Neurologi untuk evaluasi adanya insufisiensi vertebrobasiler. Pasien dianjurkan kontrol 1 minggu kemudian.

Pasien kontrol tanggal 23-3-17. Keluhan pusing berputar tidak ada, rasa oyong berkurang. Mual dan muntah tidak ada. Pemeriksaan keseimbangan sederhana dapat dilakukan. Tes koordinasi dapat dilakukan. Pemeriksaan gaze test didapatkan hasil normal. Pada pemeriksaan head impulse test dan head shaking didapatkan hasil normal. Tes penala semua frekuensi didapatkan kesan tuli sensorineural pada telinga kanan dan normal pada telinga kiri Pasien tetap diterapi dengan terapi adaptasi.

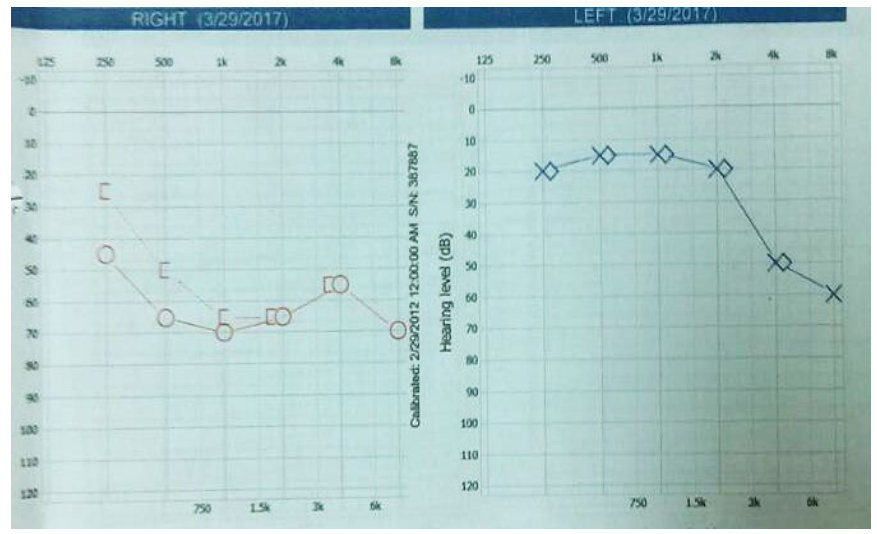

Gambar 2. Hasil audiometri

\section{DISKUSI}

Telah dilaporkan suatu kasus yang telah dilakukan prosedur terapi rehabilitasi vestibular yaitu pada laki-laki usia 65 tahun dengan diagnosis Hipofungsi vestibular perifer bilateral ec. Prebiastesis + Sudden deafness onset lama + dislipidemia. Meskipun banyak etiologi lain yang telah diteliti sebagai penyebab hipofungsi vestibuler perifer bilateral (contohnya penyakit autoimun, obat-obatan ototoksik, dan trauma), efek penuaan pada organorgan vestibular serta nuklei vestibuler memiliki peranan yang penting dalam terjadinya hipofungsi vestibuler bilateral. 3,18

Perubahan terkait usia pada morfologi neuroepitel vestibuler mencakup berkurangnya sel rambut yang signifikan, juga berkurangnya jumlah kinosilia dan stereosilia, terutama pada regio tengah atas dari ketiga ampula. Adanya penurunan fungsi metabolisme kalsium pada membran otolit usia lanjut, juga adanya iskemik mikrovaskuler juga dapat memberikan pengaruh yang besar dalam penurunan input vestibuler pada pasien usia lanjut. 17,18

Selain itu, Anamnesis riwayat penyakit dan riwayat konsumsi obat dapat membantu untuk menentukan etiologi dan faktor risiko penyakit pada pasien ini. Konsumsi obat-obatan ototoksik, presbyastasis, meningitis, neuropati, neuritis vestibuler bilateral, penyakit autoimun, tumor dan idiopatk merupakan etiologi yang sering ditemukan pada hipofungsi vestibuler perifer bilateral. ${ }^{3}$ Pada pasien ini ditemukan riwayat penurunan pendengaran telinga kanan sejak 1 tahun dan tidak ada riwayat penyakit dan konsumsi obat lainya, sehingga kausa paling mungkin pada gangguan vestibuler yang dialami pasien ini adalah terkait usia, dimana pasien sudah berumur 65 tahun. Pada pasien ini juga terdapat faktor resiko yang berhubungan dengan timbulnya kelainan ini yaitu terdapat dislipidemia dan merokok. ${ }^{24}$

Pasien dengan gangguan vestibuler seringkali mengalami masalah dengan keseimbangan serta pusing/ dizziness yang dipengaruhi posisi atau gerakan. Gejala utama ini sering disertai dengan gejala sekunder yang kemudian dapat menyebabkan hambatan pada aktivitas sehari-hari. Gejala sekunder ini mencakup lemah, letih, terbatasnya range of motion, dan meningkatnya tegangan otot (terutama di area bahu dan servikal) yang kemudian dapat menyebabkan kelelahan otot dan sakit kepala. ${ }^{9,11}$

Pada pasien ini ditemukan keluhan utama berupa pusing berputar yang dipengaruhi oleh posisi (pertama kali dirasakan saat pasien bangun dari posisi tidur) dan rasa oyong. 


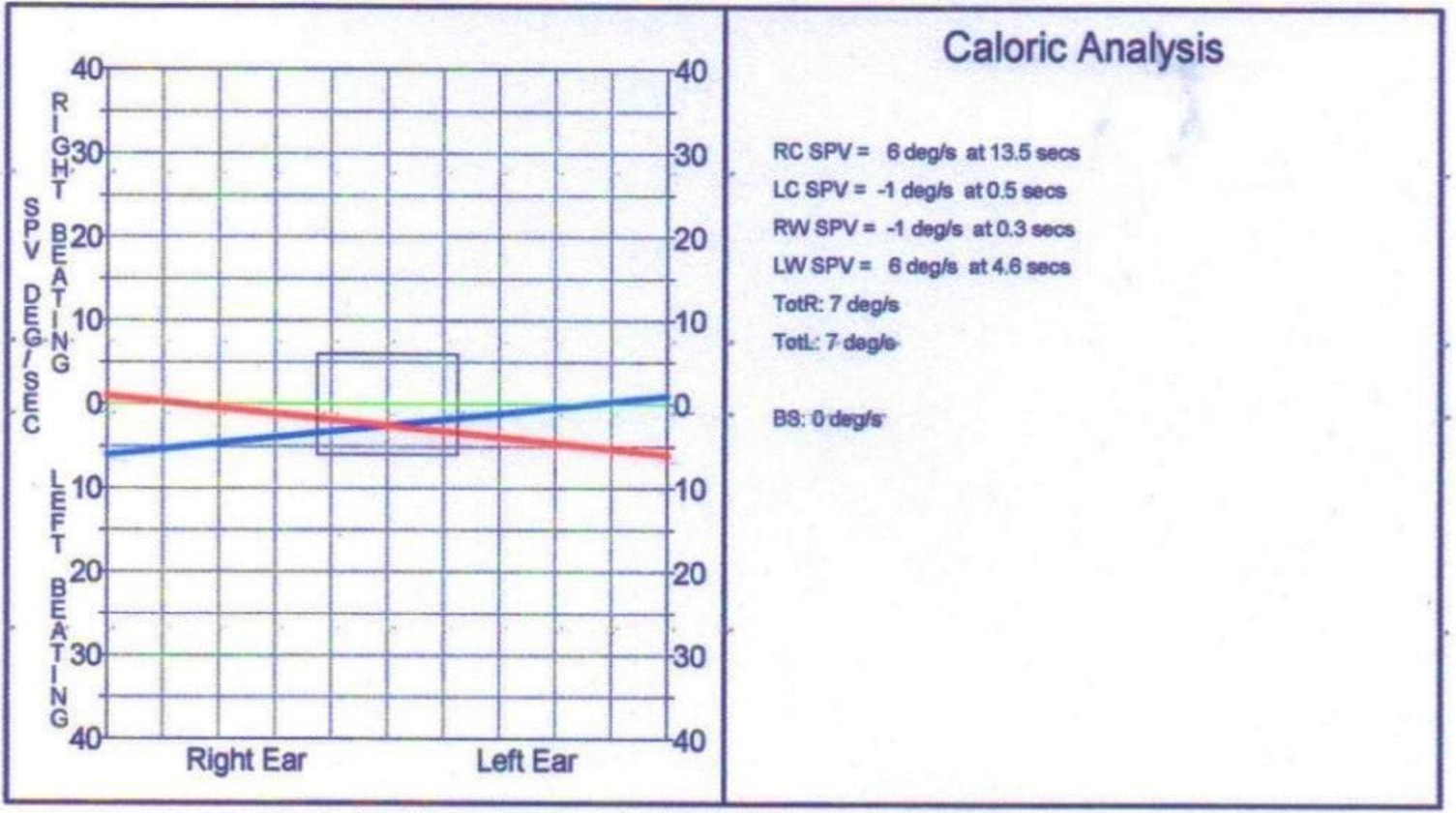

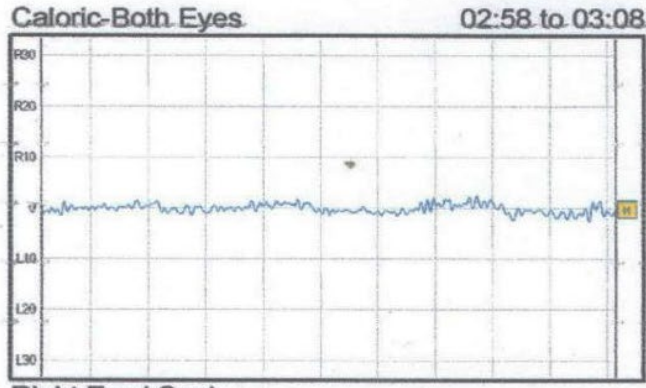

Right Ear / Cool

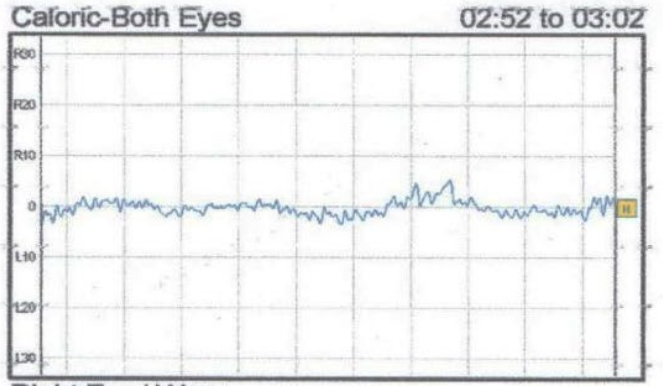

Right Ear / Warm
Caloric-Both Eyes

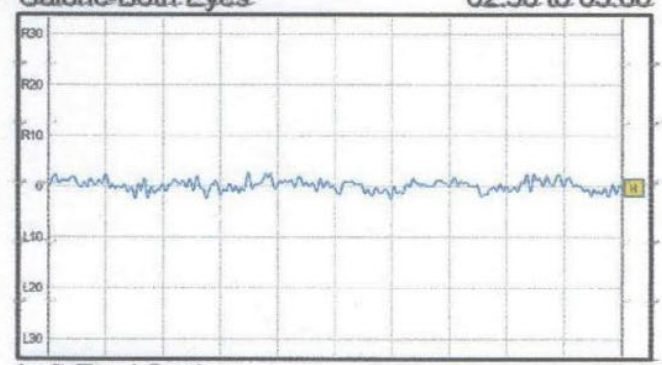

Left Ear / Cool

Caloric-Both Eyes

02:39 to 02:49

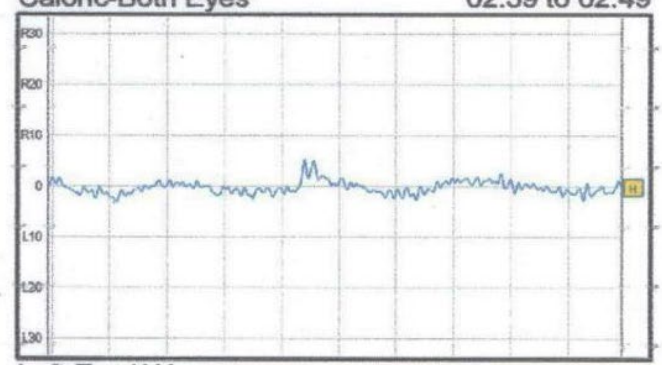

Left Ear/Warm

Gambar 3. Hasil tes kalori 
ENG-Both Eyes

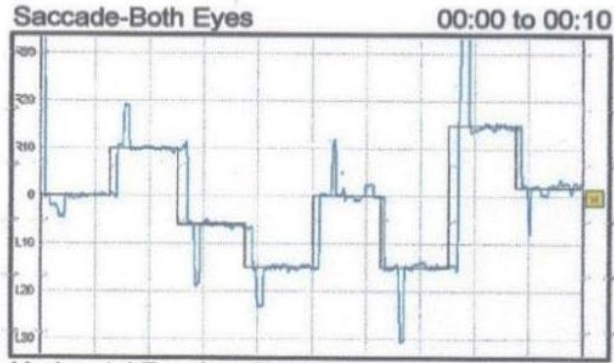

Horizontal Random Position

Gaze-Both Eyes

$00: 19$ to $00: 29$

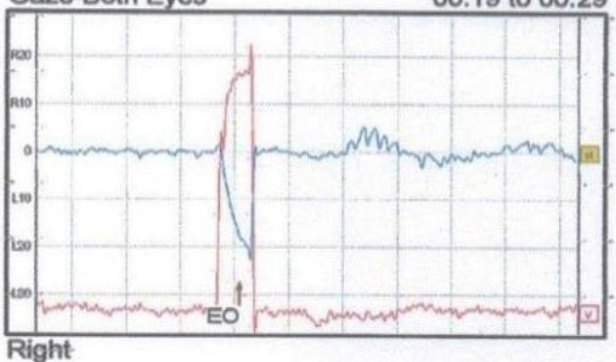

Gaze-Both. Eyes.

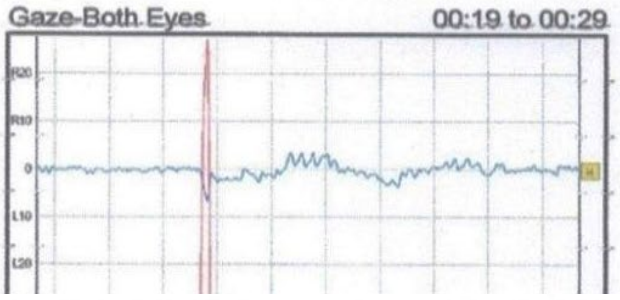

Optokinetic-Both Eyes

$00: 11$ to $00: 21$
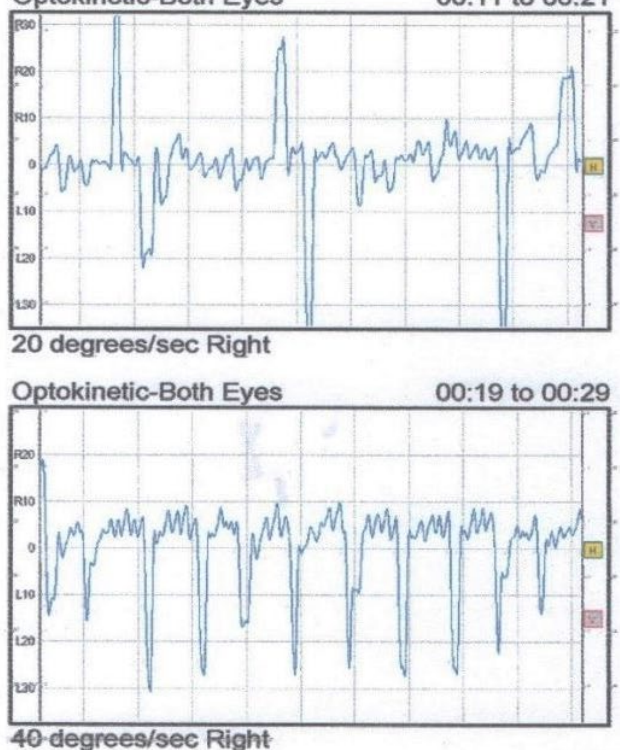

Tracking-Both Eyes 00:01 to 00:11

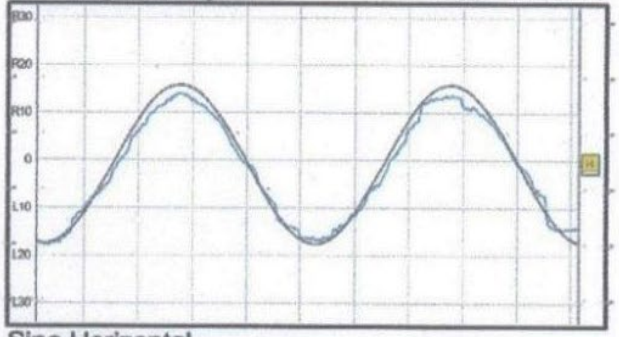

Sine Horizontal
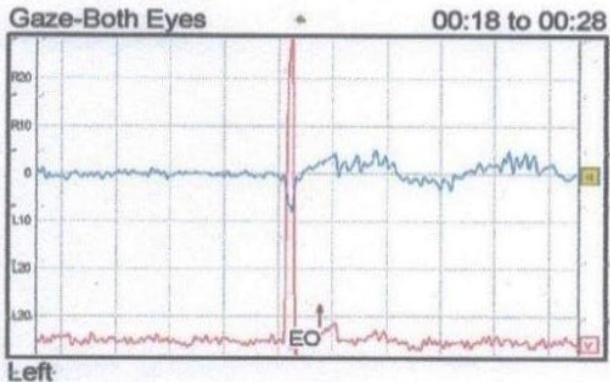

Gaze-Both.Eyes

$00: 18$ to $00: 28$
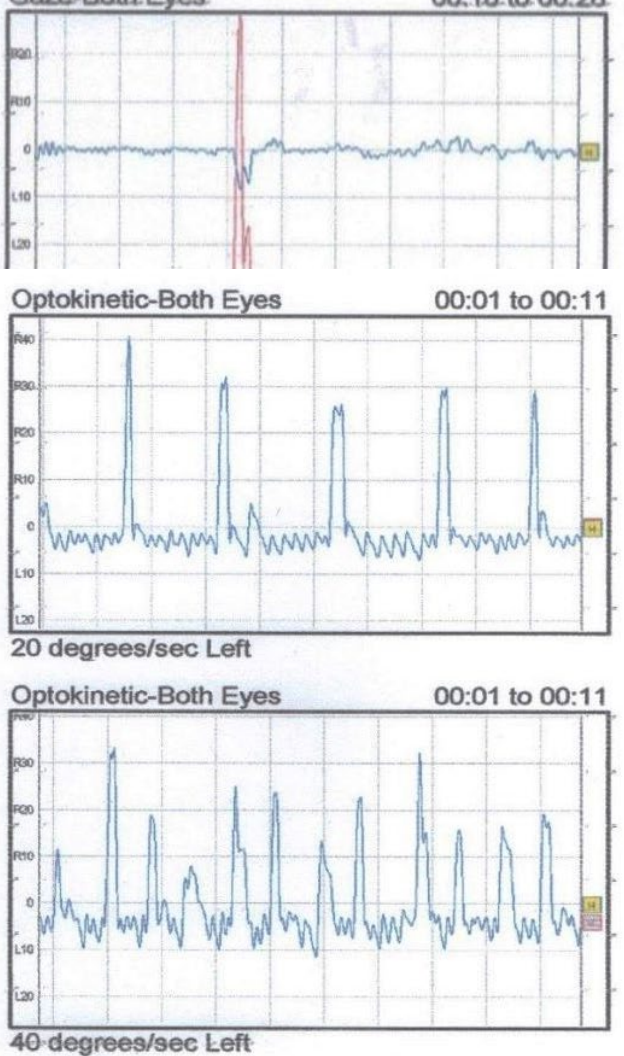

Gambar 4. Hasil tes sakadik, tes tracking, tes optokinetik, tes gaze. 
Untuk menentukan kausa dari pusing berputar dan rasa oyong ini, apakah berasal dari gangguan vestibuler atau bukan, ditentukan berdasarkan gejala klinis dan pemeriksaan khusus. Vertigo dan ketidakseimbangan yang mngakibatkan gangguan pada daya lihat dan stabilitas postural dianggap sebagai karakteristik dari hipofungsi vestibuler perifer. ${ }^{1}$ Oscilopsia atau instabilitas penglihatan yang dipengaruhi oleh gerakan dianggap sebagai karakteristik khas dari hipofungsi vestibuler perifer bilateral, dimana sepertiga dari pasien hipofungsi vestibuler perifer dilaporkan adanya oscilopsia. ${ }^{25}$ Pada pasien ini hanya ditemukan gejala khas berupa pusing berputar yang dipengaruhi oleh gerakan dan rasa oyong saat berjalan.

Pemeriksaan rutin dilakukan untuk menyingkirkan diagnosis diferensial vestibuler lain, seperti BPPV, juga penting untuk menentukan apakah gangguan vestibuler ini berasal dari perifer atau sentral. Pada pasien ini tes Romberg, Romberg dipertajam dan Stepping test dapat dilakukan pasien. Tes koordinasi yaitu Nose to finger test, Past Pointing test dan disdiadokinesis didapatkan kesan normal. Pemeriksaan manuver Dix-Hallpike didapatkan tidak ditemukan vertigo dan nistagmus, secara keseluruhan didapatkan bahwa penyakit yang diderita pasien ini diduga berasal dari vestibuler perifer.

Untuk menentukan adanya gangguan vestibuler, tes kalori merupakan tes yang paling sering dan paling mudah dilakukan. Keuntungan utamanya adalah tes kalori tersedia pada sebagian besar fasilitas kesehatan serta kemampuannya untuk menentukan sisi vestibuler yang terkena dengan cara melakukan tes pada masing-masing kanal horizontal secara terpisah. Tes kalori merupakan tes dimana merubah temperatur dari tulang temporal yang menghasilkan perubahan aliran konvektif endolimfe menjadi lamban. ${ }^{4}$ Oleh Karena itu, tes kalori digunakan sebagai gold standard untuk hipofungsi vestibuler perifer unilateral. ${ }^{5}$ Akan tetapi, pemeriksaan objektif untuk penurunan fungsi vestibuler bilateral adalah DVA. Dimana kelebihan utamanya adalah kemampuan tes ini untuk menstimulasi kanal semisirkularis dengan stimulus yang mempengaruhi kedua labirin dan memiliki frekuensi yang lebih luas dibandingkan dengan tes kalori. ${ }^{4}$ Pada pasien ini dilakukan elektronistagmografi untuk menentukan adanya gangguan vestibuler, dimana didapatkan parese kanal dengan base line shift $0^{\circ}$.

Terapi pada pasien ini adalah terapi adaptasi Terapi pada hipofungsi vestibuler perifer bilateral terutama adalah berupa terapi rehabilitasi vestibuler, dengan menggunakan prinsip adaptasi, subtitusi atau kompensasi/habituasi. Contoh terapi rehabilitasi vestibuler yang menggunakan prinsip adaptasi adalah dengan melatih pasien untuk melihat ke suatu titik tetap ketika kepala digerakkan. Teknik subtitusi mencakup input sensoris dan motoris selain dari yang biasanya terlibat dalam kontrol vestibuler langsung. Contohnya adalah sistem somatosensoris, reflek cervico-okuler, juga sistem sakkadik dan smooth pursuit (gerakan mata). Substitusi dari rapid eye movement untuk mengkompensasi hilangnya respon vestibulo-okuler dan penggunaan rangsangan visual dan proprioseptif untuk mempertahankan postur dan gaya berjalan adalah contoh dari proses subtitusi ini. ${ }^{4}$ Keberhasilan tatalaksana tergantung pada beberapa faktor. Beberapa penelitian telah melaporkan faktor-faktor yang dapat mempengaruhi kesembuhan pasien dengan hipofungsi vestibuler perifer bilateral. Pasien dengan hasil terapi yang buruk memiliki komorbid yang lebih banyak. Beberapa pasien dilaporkan mengalami depresi terkait dengan penyakitnya sehingga tidak lagi berpartisipasi dalam terapi rehabilitasinya, yang tentunya mempengaruhi hasil kesembuhan pasien tersebut. ${ }^{13}$ Herdman et al menemukan bahwa usia dan onset terjadinya gejala tidak mempengaruhi penyembuhan dan perbaikan terhadap visus di saat pergerakan kepala. ${ }^{26}$

\section{SIMPULAN}

Hipofungsi vestibuler perifer bilateral jarang terjadi jika dibandingkan dengan gangguan vestibuler lainnya. Etiologi penyakit ini bervariasi, salah satunya presbiastasis. Presbiastasis terjadi akibat adanya proses degenerasi pada system sensoris, saraf pusat dan motorik yang kemudian menyebabkan gangguan fungsi dan keseimbangan pada sistem vestibuler

Diagnosa hipofungsi vestibuler perifer bilateral ditegakkan berdasarkan anamnesa, pemeriksaan keseimbangan sederhana, dix-hallpike, tes gaze, DVA, serta pemeriksaan objektif dengan menggunakan ENG. Terapi hipofungsi vestibuler perifer bilateral terutama berupa rehabilitasi vestibuler, yang menggunakan prinsip kompensasi, adaptasi, dan subtitusi.

\section{DAFTAR PUSTAKA}

1. Alghadir $\mathrm{AH}$, Iqbal ZA, Whitney SL. An Update on Vestibular Physical Therapy. J Chinese Med Assoc. 2013; 76(1):1-8.

2. Porciuncula F, Johnson CC, Glickman LB. The effect of vestibular rehabilitation on adults with bilateral vestibular hypofunction: A systematic review. Journal of Vestibular Research. 2012; 22:283-98.

3. Hain TC, Cherchi M, Yacovino DA. Bilateral Vestibular Loss. Semin Neurol. 2013; 33:95-203.

4. Gillespie MB, Minor LB. Prognosis in Bilateral Vestibular Hypo function. The Laryngoscope. 1999; (1):35-41.

5. Herdman SJ, Clendaniel RA. Vestibuler Reflexes. Vestibular Rehabilitation. Fourth edition. Philadelphia: FA Davis Company. 2014. p.11-12.

6. Carey JP, Santina CC. Principles of Applied Vestibular Physiology. Dalam: Flint PW, Haughey $\mathrm{BH}$, Lund VJ, Niparko JK, Richardson MA, Robbins KT, et al, editors. Cummings Otolaryngology Head \& Neck Surgery. 5th ed. Philadelphia: Elsevier; 2010. 2277-304.

7. Khan S, Chang R. Anatomy of the vestibular system: A review. NeuroRehabilitation. 2013; 32(3):437-43.

8. Gacek R, Gacek MR. Anatomy of the Auditory 
and Vestibuler system. Dalam: James B. Snow, Jhon JB, editor. Ballenger's Otorhinolaringology Head and Neck Surgery. 16th ed. Illinois: BC Decker; 2010. 1-164

9. Alpini DC, Cesarani A, Brugnoni G. Human Balance and Rehab Vertigo Rehabilitation Protocols. Switzerland: Springer; 2014. 3-16.

10. Kountakis SE. Bilateral Vestibuler Weakness. Encyclopedia of Otolaryngology Head and Neck Surgery. London: Springer; 2013. 323-31.

11. Cook-Shumway A. Vestibular Rehabilitation: An Effective, Evidence-Based Treatment. Vestibuler Disorder Association. 2009; 503:1-8.

12. van de Berg $R$, van Tilburg $M$, Kingma $H$. Bilateral Vestibular Hypofunction: Challenges in Establishing the Diagnosis in Adults. ORL $J$ Otorhinolaryngol Relat Spec. 2015; 77(4):197218.

13. Herdman SJ, Clendaniel RA. Bilateral Vestibular Hypofunction. Vestibular Disorder Association. 2014; 503:1-8.

14. Schaefer SD, Wright CG, Post JD, Frenkel EP. Cis-platinum vestibular toxicity. Cancer. 1981; 47(5):857-59.

15. Agrawal $Y$, Minor LB CJ. Peripheral Vestibular Disorder. Dalam: Bailey BJ, Johnson JT, edoitors. Head and Neck Surgery Otolaryngology. 5th edition. Philadelphia: Lippincott William \& Wilkin; 2014:701.

16. Rogers C. Presbyastasis: a Multifactorial Cause of Balance Problems in The Elderly. South African Fam Pract. 2010; 52(5):431-4.

17. Kutz JW, Isaacson B, Roland PS. Aging and the auditory and vestibuler system. Dalam: Bailey BJ, Jonas TJ, editors. Bailey's Head and Neck Surgery Otolaryngology. Fifth Edition; 2014. 2615-22.

18. Suarez H, Sotta G, Roman CS, Arocena S, Ferreira E, Geisinger D. Postural response characterization in elderly patients with bilateral vestibular hypofunction. Acta Otolaryngol. 2013; 133(4):361-7.

19. Kattah JC, Talkad AV, Wang DZ, Hsieh YH, Newman-Toker DE. HINTS to diagnose stroke in the acute vestibular syndrome: Three-step bedside oculomotor examination more sensitive than early MRI diffusion-weighted imaging. Stroke. 2009; 40(11):3504-10.

20. Goebel JA, Hullar TE. Vertigo, Disequilibrium, and Dizziness. Dalam: Harris JP, Weisman MH. Head and Neck Manifestations of Systemic Disease. London: Informa; 2007. 369-77.

21. Sharma V, Shah RK. Conventional Vestibular Function Tests vs Butterfly Vestibulometry in Peripheral Vertigo. Nepal Journal of Medical Sciences. 2014; 3(1):31-7.

22. Gans RE. Vestibular-Cognitive Integration: A Concussion Case Study. J Otolaryngol Res. 2017; 6(4):1-6.

23. Hillier SI, McDonnell M. Vestibular rehabilitation for unilateral peripheral vestibular dysfunction (Review). Cochrane Database of Systematic Reviews 2011; 2:1-75

24. Ohhira S, Miyahara $H$, Fujita $N$. Ueda $T$, Yamanaka T, Murai T, Tosihiro, et al. Influence of Hyperlipidemia and Smoking on Age-related Changes in Caloric Response and Puretone Hearing. Acta Otolaryngol. 1998; 533:40-5

25. Tee LH, Chee NWC, Edin F, Orl F. Vestibular
Rehabilitation Therapy for the Dizzy Patient. Ann Acad Med Singapore. 2005; 34(4):289-94.

26. Herdman SJ, Schubert MC, Das VE, Tusa RJ. Recovery of Dynamic Visual Acuity in bilateral Vestibular Hypofunction. Arch Otolaryngol Head Neck Surg. 2003; 129:819-824. 